\title{
Analysis of Human Factor Engineering in Banana Harvesting Tools in Tamil Nadu, India
}

\author{
Edwin Benjamin $^{1^{*}}$ and D. Anatha Krishnan ${ }^{2}$ \\ ${ }^{1}$ Department of Agriculture Engineering, Sri Shakthi Institute of Engineering and Technology, \\ Coimbatore, India \\ ${ }^{2}$ Tamil Nadu Agricultural University, Coimbatore, India \\ *Corresponding author
}

\begin{abstract}
A B S T R A C T
Harvesting of banana bunch is a tedious work in conventional type harvesting. Various type hand tools are used for conventional type banana harvesting and it is manufactured in the local smithy shop without any design consideration, in crude manner and also with huge variations in sizes, shape and weight etc. So an human factor study was conducted on banana bunch harvesting operation with various locally available knives. In this study, various crop and tool parameters were selected. Various anthropometric data were considered as human parameters. The evaluations of conventional type knives showed that $3 \mathrm{~mm}$ and $6 \mathrm{~mm}$ thick knives were commonly available in local market. Using these available data, the cutting force required to harvest banana peduncle was measured in laboratory as well as in field with the different parameters which affect the cutting force. The ergonomic and anthropometric data were also considered for improving the knives design. The oxygen consumption rate of the subjects was measured using computerized ambulatory metabolic measurement system K4b2. The results showed that the average cutting energy of subjects varies from 1010.5 to $1282.6 \mathrm{Jm}^{-2}$ and Average energy expenditure varies from 20.53 to $21.84 \mathrm{KJ} \mathrm{min}^{-1}$ during the conventional operation. Finally this study suggested a guide lines for developing new ergo refined knife. Test results proved that $3 \mathrm{~mm}$ knives required minimum cutting energy compared to $6 \mathrm{~mm}$. The material of knives also influenced the cutting force. Ergonomic study also suggested that the length and diameter of knife handle should be $150 \mathrm{~mm}$ and $35 \mathrm{~mm}$ respectively on the basis of anthropometric data available in anthropometric data book prepared by CIAE Bhopal. Weight of the knife above $400 \mathrm{~g}$ gave ergonomically good result.
\end{abstract}

\section{Keywords}

Human factor, Banana harvesting, ergonomics, anthropometry, knives design, K4b2, cutting force

Article Info

Accepted:

15 February 2020

Available Online:

10 March 2020

\section{Introduction}

In India, banana (Musa spp.) is one of the traditional fruits cultivated by man from prehistoric times. Banana ranks next to mango in area and production, occupying an area of about 83 lakh hectares with an annual production of 46.26 lakh tons. The important banana growing states in India are Tamil Nadu, Maharashtra, Karnataka, Andhra Pradesh, Gujarat, Kerala, Assam, West Bengal, and Bihar. However, the present production of banana in the country is highly inadequate. According to statistics of the 
National Horticultural Board, Tamil Nadu is in the highest position in area of banana cultivation and producing state in India. Virupakshi, Robusta, Red banana, Poovan, Rasthali, Nendran, Monthan, Karpuravalli, Sakkai, Peyan and Matti are the main banana verities grown in Tamil Nadu.

Two methods of harvesting are commonly practiced for harvesting banana bunches. In one method, two types of workers are required to harvest banana, cutter and backer. The cutter cuts down the plant with his machete while the backer waits for the cut stem to settle on a thick cushion on his shoulder. The cutter then chops the stem to enable the daughter plant to take over as the main stalk. The backer carries the banana fruit bunch to the packing shed or market for sale. It can also be transported in carts. The second method of harvesting does not require the cutting of the tree. A long wooden pole of $1.80 \mathrm{~m}$ long with cutting knife at the edge is used for harvesting the banana. This method requires two persons. One person cut the bunch and other person catches the falling bunch. But in some areas, single person alone does this work. Banana bunch harvesting is one of the tedious jobs. Back pain, shoulder pain, musculoskeletal injuries etc are the common ailments in the banana harvesting workers. All type of harvesting systems causes musculoskeletal problems. Ergonomics is the scientific study of the relationship between the men and his working environment, which include ambient conditions, tools and materials, method of work and organizational work. Average weight of banana bunch will be $25 \mathrm{~kg}$ to 35 $\mathrm{kg}$ and in the case of Robusta and pooven it will go more than $55 \mathrm{~kg}$ to $60 \mathrm{~kg}$. So the conventional type harvesting mentioned above causes drudgeries and workers face many types of muscoskeletal problems. So the evaluation of existing practices of banana bunch harvesting with conventional tools study conducted. Chancellor (1958) stated that when slicing with a knife, friction caused the fibers or parts of fibers to adhere to the knife-edge. As the movement continued, the fibers became separated from the rest of the stem in the region of the knife but were still attached. McRandal and McNulty (1978)investigated the impact cutting behavior of forge crops theoretically and experimentally. Geoff and Shlomowitz (1992) investigated on different types of hand tools of various designs, sizes and shapes are used for cane harvesting. Chattopadhyay and Pandey (1999) conducted laboratory experiment to determine the impact cutting energy while cutting single stem of forage sorghum by the knife of a flail harvesting machine. Neves et al., (2001) investigated on the blade materials commonly used in cane harvesting and concluded that the knife should be made from a material that was harder than what it was cutting. Koloor and Ghaffar (2007) investigated on the effect of blade parameters on the cutting energy on soybean stems. An impact shear test apparatus was designed and constructed to measure the energy required for cutting soybean plant stems. Kanchan et al., (2010) analyzed the anthropometrical relationships within and between hand and foot dimensions. The study was conducted on 240 Rajputs (120 males and 120 females) from North India. Sawkar (1999) showed that mean heart rate of picking of stalks and stubbles, sowing, transplanting, inter culturing, weeding and harvesting of wheat and jowar crop were 101.00 \pm 5.30 , $110.60 \pm 4.20,118.60 \pm 15.10, \quad 131.00 \pm 7.00$, $109.10 \pm 7.1, \quad 126.00 \pm 7.00$ and $123.00 \pm 5.0$ beats $\mathrm{min}^{-1}$, respectively. Saha et al., (1979) based on their study on acceptable work load for Indian workers reported that the acceptable workload for average young Indian worker while performing work under comfortable thermal environmental conditions would lie somewhere between 30 per cent and 40 per cent of an individual's maximum 
aerobic power /capacity. Brockway (1978) stated that the heart beat rate predicted the energy expenditure. This study correlated the heart beat rate, oxygen consumption by indirect calorimetry and indicated the possibility of extrapolating the energy expenditure from the stabilized heart beat rate.

\section{Materials and Methods}

A preliminary survey on the conventional tools used for banana bunch harvesting was conducted. Five banana bunch harvesting knives collected from different parts of Tamil Nadu (Fig.1) and all the major parameters affecting the performance of the knives were measured.

Thickness of blade, length of the blade, width of the blade, handle diameter, handle length, weight of the knife and curvature of the knives are the major parameters affecting the performance of the knives Curvature of cutting knives affects the penetration of knife into the peduncle and shearing action of the knives. Curvature studies were conducted for the collected five knives with the help of AUTO CAD and excel software.

The parameters such as the weight of the knives, blade length, handle length, handle diameter and total length of the suggested knife was designed based on the anthropometric data of agricultural workers of Tamil Nadu available in the data bank book "Anthropometric and strength data of Indian agricultural workers for farm equipment design" (Gite et al., 2009). The handle length was designed based on the $95^{\text {th }}$ percentile of hand breadth across thumb applicable to Tamil Nadu agricultural workers as given in the anthropometric data book. The handle diameter was determined based on the $5^{\text {th }}$ percentile of the palm width and hand grip diameter. The length and width of the blades were designed based on the subjective evaluation of different banana bunch harvesting knives. The laboratory test rig consists of an impact cutting test rig to determine the impact energy required for different varieties and diameter of banana peduncle at different settings of the variables

Age and medical fitness main criteria were used for the selection of subjects. Three male workers in the age group of 32 to 34 years were chosen considering their experience in the operation of banana plantations for the investigation. The height and weight of the subjects varies from 1654.0 to $1700.0 \mathrm{~mm}$ and 65.1 to $68.4 \mathrm{~kg}$ respectively. The following medical and bio-clinical investigations were conducted to assess the medical fitness of selected subjects; Electro Cardio Graph (ECG), Blood pressure and Bio-clinical analysis. The selected three male subjects were calibrated in the laboratory by indirect assessment. For indirect assessment of oxygen uptake for the harvesting of banana bunch, the heart rate of the subject while running on a treadmill and the corresponding oxygen uptake have to be measured and plotted. The heart rate of the subject during exercise in the treadmill was measured using $\mathrm{K} 4 \mathrm{~b}^{2}$. It is an electrical medical device designed to perform pulmonary function tests. The $\mathrm{VO}_{2} \max$ for all the subjects was computed and recorded.

The evaluation of banana bunch harvesting was conducted with selected subjects at TNAU farm. The selected three subjects participated in the investigation. Each subject was evaluated for duration of half an hour with all banana bunch harvesting practices. In field evaluation, collected heart rate required for harvesting operation of each subject by using heart rate monitor. Computed the ergonomic data like maximum aerobic capacity, energy cost of operation, grading of energy cost of operation, work-rest cycle, 
Acceptable Work Load (AWL), Limit of Continuous Performance (LCP) and the assessment of Overall Discomfort Rating (ODR) and Body Part Discomfort Score (BPDS) for the operation of the selected the conventional knives. Heart rate and oxygen consumption rate are the pertinent parameters for assessing the human energy required for performing various types of operation (Curteon, 1947). The acceptable workload (AWL) for Indian workers was the work consuming 35 per cent of $\mathrm{VO}_{2} \max$ (Saha et al., 1979). The trials for ease of operation rating for all the selected banana bunch harvesting practices were carried out in the same field where physiological measurements were taken by using ' 10 - point psychophysical rating scale'. At the end of each trial with the entire bunch harvesting operation, the subject was asked to indicate their overall safety level on the 10-point rating scale.

\section{Results and Discussion}

In banana bunch harvesting machetes manufactured in the local smithy shops without any design consideration were used. The machetes vary in size, shape and weight from place to place. Hence, five types of commonly used banana harvesting knives were collected from various banana growing parts of Tamil Nadu. The various features of the collected knives were measured and are presented in table 1 .

Four models $\left(\mathrm{K}_{2}\right.$ to $\left.\mathrm{K}_{5}\right)$ of collected models of cutting knife were made of mild steel of thickness $6 \mathrm{~mm}$, whereas Sathyamangalam model $\left(\mathrm{K}_{1}\right)$ cutting knife was made of spring steel of $3 \mathrm{~mm}$ thickness with least weight of $362 \mathrm{~g}$.

Thickness of blade of Sathyamangalam model knife $\left(\mathrm{K}_{1}\right)$ had minimum thickness of $3 \mathrm{~mm}$ and all other model knives have a thickness of
$6 \mathrm{~mm}$. Width of the blade is observed that the width was varying from 40 to $60 \mathrm{~mm}$ rang. The Sathyamangalam model knife $\left(\mathrm{K}_{1}\right)$ has maximum width of $60 \mathrm{~mm}$ and Vadavalli model II $\left(\mathrm{K}_{4}\right)$ knife has minimum width of 45 $\mathrm{mm}$. The length of the blade varied from 300 to $193 \mathrm{~mm}$. Thudiyalur model I knife $\left(\mathrm{K}_{3}\right)$ has maximum blade length of $300 \mathrm{~mm}$ and Thudiyalur model II knife $\left(\mathrm{K}_{5}\right)$ showing minimum thickness of $193 \mathrm{~mm}$. The handle diameter of the conventional banana bunch harvesting knife was varying between 25 and $40 \mathrm{~mm}$. Thudiyalur model II knife $\left(\mathrm{K}_{5}\right)$ has maximum handle diameter of $40 \mathrm{~mm}$ and Sathyamangalam model knife $\left(\mathrm{K}_{1}\right)$ has minimum handle diameter of $25 \mathrm{~mm}$. The handle length of the banana bunch harvesting knives was varying between 120 and $165 \mathrm{~mm}$. The maximum handle length of $165 \mathrm{~mm}$ was observed in Thudiyalur model II knife $\left(\mathrm{K}_{5}\right)$ and minimum handle length of $120 \mathrm{~mm}$ was observed in Vadavalli model II knife $\left(\mathrm{K}_{4}\right)$. The bevel angle of the conventional banana bunch harvesting knives was varying from $15^{0}$ to $27^{0}$. From the above observations, it is observed that Thudiyalur model II knife $\left(\mathrm{K}_{5}\right)$ has maximum bevel angle of $27^{0}$ and Sathyamangalam model knife $\left(\mathrm{K}_{1}\right)$ has minimum bevel angle $15^{\circ}$. The weight of conventional type banana bunch harvesting knives varied from 362 to $568 \mathrm{~g}$. From the above observations, it is found that Thudiyalur model I knife $\left(\mathrm{K}_{3}\right)$ has more weight and Sathyamangalam model knife $\left(\mathrm{K}_{1}\right)$ having minimum value of $362 \mathrm{~g}$.

Profile analysis and curvature studies were conducted for the conventional type knives with AUTO CAD and excel software. The equations of the curvature of the cutting edge of the knives were found out in which the height of the tool was defined by $\mathrm{X}$ coordinate and the width of the tool was defined by $\mathrm{Y}$ coordinate. Based on the subjective evaluation, the performance of harvesting operation increased with decrease 
in curvature. The ranking of curvature based on performance is $\mathrm{K}_{1}, \mathrm{~K}_{2}, \mathrm{~K}_{3}, \mathrm{~K}_{4}$ and $\mathrm{K}_{5}$.

\section{Human factor engineering of conventional type banana bunch harvesting Method using collected knives}

The comparison of the traditional type banana bunch harvesting using different knives conducted in field and the observations are given in the table. 2 .

Among these models, the Sathyamangalam model $\left(\mathrm{K}_{1}\right)$ was showing better performance with less weight compared to other models. So weight of the knife is affected the human performance in banana harvesting practice. The result showed that the mean value of Sathyamangalam model $\left(\mathrm{K}_{1}\right)$ knife showing less heart rate and oxygen consumption in conventional type knives. It is observed that the mean value of energy expenditure of subjects for banana harvesting practices with different knives varied from 20.53to $21.84 \mathrm{kJmin}^{-1}$.The order of ranking of knives based on energy cost was Sathyamangalam model $\left(\mathrm{K}_{1}\right)$, Vadavalli model II $\left(\mathrm{K}_{4}\right)$, Thudiyaur model I $\left(\mathrm{K}_{3}\right)$, Vadavalli model I $\left(\mathrm{K}_{2}\right)$ and Thudiyaur model II $\left(\mathrm{K}_{5}\right)$. The mean values of oxygen consumption rate (OCR) interms of percent $\mathrm{VO}_{2}$ max for banana bunch harvesting varied from 38.4 to 42.6 per cent. From table 2, it is observed that the OCR was more than acceptable workload for all model $\mathrm{K}_{1}, \mathrm{~K}_{2}, \mathrm{~K}_{3}, \mathrm{~K}_{4}$ and $\mathrm{K}_{5}$.In general the work pulse values calculated for banana bunch harvesting operation with knives $\mathrm{K}_{2}, \mathrm{~K}_{3}, \mathrm{~K}_{4}$, $\mathrm{K}_{5}$ and $\mathrm{K}_{1}$ were slightly higher than the LCP value of 40 beats $\mathrm{min}^{-1}$, which is a clear indicative of the fact that none of these bunch harvesting practices could be performed for longer duration without adequate rest.

The table. 3 showing that among these five models of banana bunch cutting knives, $\mathrm{K}_{1}$ and $\mathrm{K}_{2}$ recorded the highest ease of operation rating, the knives $\mathrm{K}_{1}$ and $\mathrm{K}_{5}$ recorded light discomfort, $\mathrm{K}_{2}$ and $\mathrm{K}_{5}$ knives showing moderate safe and moderately no danger. The knife $\mathrm{K}_{1}$ showing the lower value of ODR and BPDS during the ergonomics calculations.

All pertinent anthropometric data required for the design of handle for the suggested banana bunch harvesting knife was taken from "anthropometric and strength data of Indian agricultural workers for farm equipment design" (Gite et al., 2009), published by CIAE, Bhopal were given in table 4.

Table.1 Details of traditional banana bunch harvesting knives

\begin{tabular}{|c|c|c|c|c|c|c|c|c|}
\hline $\begin{array}{c}\text { Sl. } \\
\text { No }\end{array}$ & Model & $\begin{array}{c}\text { Knife } \\
\text { length(mm) }\end{array}$ & $\begin{array}{c}\text { Handle } \\
\text { length(mm) }\end{array}$ & $\begin{array}{c}\text { Handle } \\
\text { diameter } \\
(\mathbf{m m})\end{array}$ & $\begin{array}{c}\text { Weight } \\
(\mathbf{g})\end{array}$ & $\begin{array}{c}\text { Thickness } \\
(\mathbf{m m})\end{array}$ & $\begin{array}{c}\text { Width } \\
(\mathbf{m m})\end{array}$ & $\begin{array}{c}\text { Material } \\
\text { used }\end{array}$ \\
\hline $\mathbf{K}_{\mathbf{1}}$ & $\begin{array}{c}\text { Sathyamangalam } \\
\text { model }\end{array}$ & 240.0 & 130.0 & 25.0 & 362 & 3 & 60.0 & $\begin{array}{c}\text { Spring } \\
\text { steel }\end{array}$ \\
\hline $\mathbf{K}_{\mathbf{2}}$ & Vadavalli model I & 295.0 & 140.0 & 35.0 & 532 & 6 & 40.0 & M.S \\
\hline $\mathbf{K}_{\mathbf{3}}$ & Thudiyalur model I & 300.0 & 130.0 & 35.0 & 568 & 6 & 50.0 & M.S \\
\hline $\mathbf{K}_{\mathbf{4}}$ & Vadavalli model II & 280.0 & 120.0 & 35.0 & 494 & 6 & 45.0 & M.S \\
\hline $\mathbf{K}_{\mathbf{5}}$ & Thudiyalur model II & 193.0 & 165.0 & 40.0 & 544 & 6 & 50.0 & M.S \\
\hline
\end{tabular}


Table.2 Ergonomical analysis of conventional type banana bunch harvesting method using different conventional knives

\begin{tabular}{|c|c|c|c|c|c|c|c|}
\hline $\begin{array}{l}\text { Harvesting } \\
\text { operation } \\
\text { using } \\
\text { different } \\
\text { knives }\end{array}$ & $\begin{array}{l}\text { The mean } \\
\text { heart rate, } \\
\text { beats } \text { min }^{-1}\end{array}$ & $\begin{array}{r}\mathbf{V O} \mathbf{O}_{2} \\
1 \mathrm{~min}^{-1}\end{array}$ & $\begin{array}{c}\text { Energy } \\
\text { expenditure, } \\
\text { KJ min }\end{array}$ & $\begin{array}{c}\text { Oxygen } \\
\text { consumption } \\
\text { rate as percent } \\
\text { of } \mathrm{VO}_{2} \max (\%)\end{array}$ & $\begin{array}{c}\text { Acceptable } \\
\text { workload } \\
\left(35 \% \mathrm{VO}_{2} \text { max }\right)\end{array}$ & $\begin{array}{l}\Delta \mathrm{HR} \\
\text { beats } \\
\text { min }^{-1}\end{array}$ & $\begin{array}{c}\text { LCP } \\
40 \\
\text { beats } \\
\text { min }^{-1}\end{array}$ \\
\hline$K_{1}$ & 104 & 0.90 & 20.53 & 38.4 & $>\mathrm{AWL}$ & 38 & $>\mathrm{LCP}$ \\
\hline $\mathbf{K}_{2}$ & 108 & 1.03 & 21.63 & 41.3 & $>A W L$ & 45 & $>\mathrm{LCP}$ \\
\hline $\mathbf{K}_{3}$ & 108 & 1.00 & 20.93 & 40.8 & $>$ AWL & 45 & $>\mathrm{LCP}$ \\
\hline$K_{4}$ & 106 & 1.01 & 21.06 & 38.9 & $>A W L$ & 44 & $>\mathrm{LCP}$ \\
\hline$K_{5}$ & 109 & 1.05 & 21.84 & 42.6 & $>\mathrm{AWL}$ & 47 & $>\mathrm{LCP}$ \\
\hline
\end{tabular}

Table.3 Comparison of rating of perceived exertion of conventional type banana bunch harvesting

\begin{tabular}{|l|l|l|l|l|}
\hline $\begin{array}{l}\text { Harvesting } \\
\text { operation } \\
\text { using } \\
\text { different } \\
\text { knives }\end{array}$ & ODR Scale & $\begin{array}{l}\text { Overall safety } \\
\text { rating(OSR) }\end{array}$ & $\begin{array}{l}\text { Overall ease of } \\
\text { operation(OER) }\end{array}$ & $\begin{array}{l}\text { BPDS } \\
\text { Score }\end{array}$ \\
\hline $\mathbf{K}_{\mathbf{1}}$ & $>$ Light discomfort & $\begin{array}{l}\text { > Slight safe \& light } \\
\text { danger }\end{array}$ & $<$ Easy & 42.7 \\
\hline $\mathbf{K}_{\mathbf{2}}$ & <Moderate discomfort & $\begin{array}{l}\text { < Moderately safe \& } \\
\text { moderately no danger }\end{array}$ & $<$ Easy & 43.3 \\
\hline $\mathbf{K}_{\mathbf{3}}$ & $>$ Moderate discomfort & $\begin{array}{l}\text { > Moderately safe \& } \\
\text { moderately no danger }\end{array}$ & $>$ Less difficult & 52.7 \\
\hline $\mathbf{K}_{\mathbf{4}}$ & <Moderate discomfort & $\begin{array}{l}\text { > Moderately safe \& } \\
\text { moderately no danger }\end{array}$ & $>$ Less difficult & 56.7 \\
\hline $\mathbf{K}_{\mathbf{5}}$ & $>$ Light discomfort & $\begin{array}{l}\text { < Moderately safe \& } \\
\text { moderately no danger }\end{array}$ & $<$ Less difficult & 50.7 \\
\hline
\end{tabular}

Table.4 Human parameters required for the design of handle and banana stand

\begin{tabular}{|c|c|c|c|c|c|c|}
\hline \multirow[t]{2}{*}{ S.No } & \multirow[t]{2}{*}{ Parameter } & \multicolumn{2}{|c|}{$\begin{array}{l}\text { Percentile } \\
\text { values }\end{array}$} & \multicolumn{2}{|c|}{ Range of values } & \multirow[t]{2}{*}{ Mean } \\
\hline & & $5^{\text {th }}$ & $95^{\text {th }}$ & Maximum & Minimum & \\
\hline 1 & Shoulder grip length, mm & 612 & 863 & 882 & 520 & 738 \\
\hline 2 & Hand length, mm & 164 & 197 & 214 & 148 & 181 \\
\hline 3 & Hand breadth across thumb, mm & 86 & 111 & 135 & 74 & 72 \\
\hline 4 & Grip diameter (inside), $\mathrm{mm}$ & 43 & 56 & 62 & 37 & 49 \\
\hline 5 & $\begin{array}{l}\text { Middle finger palm grip diameter, } \\
\mathrm{mm}\end{array}$ & 24 & 32 & 36 & 21 & 28 \\
\hline 6 & Forearm hand length, mm & 416 & 495 & 530 & 375 & 455 \\
\hline
\end{tabular}


Table.5 Cutting energy measurement of conventional model banana bunch harvesting knives

\begin{tabular}{|c|c|c|c|}
\hline S.No & \multicolumn{2}{|c|}{ Model } & Average cutting energy per unit area $\left(\mathbf{j m}^{-\mathbf{2}}\right)$ \\
\hline $\mathbf{1}$ & Sathyamangalam model & $\mathrm{K}_{1}$ & 1116.6 \\
\hline $\mathbf{2}$ & Vadavalli model I & $\mathrm{K}_{2}$ & 1010.5 \\
\hline $\mathbf{3}$ & Thudiyalur model I & $\mathrm{K}_{3}$ & 1282.6 \\
\hline $\mathbf{4}$ & Vadavalli model II & $\mathrm{K}_{4}$ & 1185.6 \\
\hline $\mathbf{5}$ & Thudiyalur model II & $\mathrm{K}_{5}$ & 1172.3 \\
\hline
\end{tabular}

Fig.1 Conventional type tools used for banana bunch harvesting

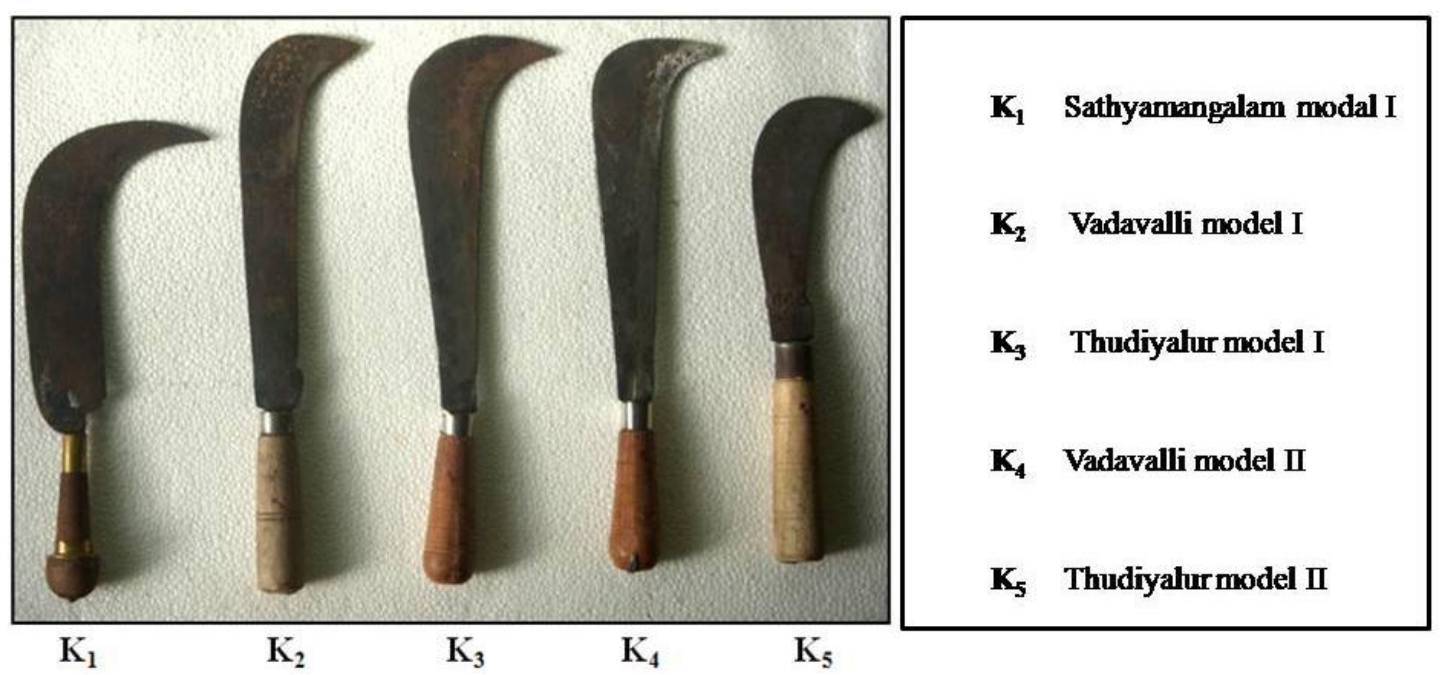

The diameter of the suggested banana bunch harvesting knife was designed based on the $5^{\text {th }}$ percentile value of the Hand length, Grip diameter (inside) and Middle finger palm grip diameter. The $5^{\text {th }}$ percentile value of forearm hand length and shoulder grip length or $95^{\text {th }}$ percentiles of hand breadth across thumb were considered for the leverage force calculation.

The cutting energy required for each knife was measured and analyzed in the laboratory and the calculated values are furnished in table 5 .
From above table, it is observed that the lowest cutting energy was recorded in Vadavalli model I $\left(\mathrm{K}_{2}\right)$ knife for cutting the banana peduncle as $1010.5 \mathrm{Jm}^{-2}$. It was followed by Sathyamangalam model $\left(\mathrm{K}_{1}\right)$ requiring $1116.6 \mathrm{Jm}^{-2}$ cutting energy.

Summary and conclusions of the study are as follows:

Human factor engineering analyses of conventional banana bunch harvesting knives were carried out and the result were summarised. The lowest cutting energy was recorded in Vadavalli model $\mathrm{I}\left(\mathrm{K}_{2}\right)$ knife 
followed by Sathyamangalam model $\left(\mathrm{K}_{1}\right)$.Among these five models of banana bunch cutting knives, $\mathrm{K}_{1}$ and $\mathrm{K}_{2}$ recorded the highest ease of operation rating. The order of ranking of knives based on energy cost was $\mathrm{K}_{1}, \mathrm{~K}_{4}, \mathrm{~K}_{3}, \mathrm{~K}_{2}$ and $\mathrm{K}_{5}$.In general, the ranking of these five knives based on ergonomic evaluation is $\mathrm{K}_{1}, \mathrm{~K}_{2}, \mathrm{~K}_{5}, \mathrm{~K}_{3}$, and $\mathrm{K}_{4}$.Form the above study, the new design parameters were optimized for ergo refined banana bunch harvesting knife. The blade thickness is taken as $3 \mathrm{~mm}$ for the banana bunch harvesting knife due to the better performance in field study. The length of the knives was varied from 300 to $500 \mathrm{~mm}$ and width 50 to $60 \mathrm{~mm}$. The suggested weight of ergo refined knife is ranging from $450 \mathrm{~g}$ to $520 \mathrm{~g}$. Handle length of $150 \mathrm{~mm}$ and handle diameter of $35 \mathrm{~mm}$ were selected according to the anthropometric data.

\section{References}

Brockway, J.W. 1978. Escape from the chamber, alternate method for large animal calorimetry. Proceedings of the Nutrition Society, 31(1): 13-18.

Chancellor, W.J. 1958. Energy requirements for cutting forage. Journal of Agricultural. Engineering, 39 (10):633640.

Chattopadhyay, P. S and K. P. Pandey. 1999. Effect of Knife and Operational Parameters on Energy Requirement in Flail Forage Harvesting. Journal of Agricultural Engineering Research, 73, 3-12.

Curteon, T.K. 1947. Physical fitness appraisal and guidance. The C.V. Mosby Co., St Louis.
Geoff, B. and R. Shlomowitz. 1992. The Lag in the Mechanization of the Sugarcane Harvest: Some Comparative Perspectives. Agricultural History, 66 (3):61.

Gite, L. P., J. Majumder, C. R. Mehta and Abijit K. 2009. Anthropometric and strength data of Indian agricultural workers for farm equipment design. Coordinating cell AICRP on Ergonomics and Safety in Agriculture, CIAE Bhopal.

Kanchan, T., K. Krishan, A. Sharma, G. Ritesh and Menezes. 2010. A study of correlation of hand and foot dimensions for personal identification in mass disasters. Forensic Science International, 199: 112.e1-112.e6.

Koloor, R. T., and G. Kiani. 2007. Soybean stems cutting energy and the effects of blade parameters on it. Pakistan Journal of Biological Sciences, 10 (9): 15321535.

McRandal, D. M. and P. B. McNulty. 1978. Impact cutting behaviour of forage crops I. Mathematical models and laboratory tests. Journal of Agricultural Engineering Research, 23. (3):313-328.

Saha, P. N. S.R Datta, P. K. Banerjee and G. G. Narayane. 1979. An acceptable workload for Indian workers. Ergonomics, 22:1069-1071.

Sawkar, S. P. 1999. Ergonomic evaluation on occupational workload, posture and musculoskeletal problems of the female agricultural labourers in Dharwad, Karnataka, state Unpublished Ph.D thesis, SNDT, women's university, Mumbai.

\section{How to cite this article:}

Edwin Benjamin and Anatha Krishnan, D. 2020. Analysis of Human Factor Engineering in Banana Harvesting Tools in Tamil Nadu, India. Int.J.Curr.Microbiol.App.Sci. 9(03): 19411948. doi: https://doi.org/10.20546/ijcmas.2020.903.226 